\title{
Development of an E-Flipped Classroom Learning Model to Improve Mathematics Students' High Level Thinking Ability
}

\author{
Andi Ika Prasasti Abrar ${ }^{1}$, Hamzah $\mathrm{Upu}^{2}$, Asdar $^{3}$ \\ ${ }^{1}$ Department of Educational Science, Universitas Negeri Makassar \\ Jln. Bonto Langkasa Kampus Gunung Sari Baru, Makassar, Indonesia \\ Universitas Islam Negeri Makassar \\ J1. Sultan Alauddin No.63, Romangpolong, Gowa, Indonesia \\ Email: ika.prasastiabrar [AT] uin-alauddin.ac.id \\ ${ }^{2}$ Department of Mathematics and Science, Universitas Negeri Makassar, \\ Jln. Daeng Tata I, Makassar, Indonesia \\ Email: hamzahupu [AT] unm.ac.id \\ ${ }^{3}$ Department of Mathematics and Science, Universitas Negeri Makassar, \\ Jln. Daeng Tata I, Makassar, Indonesia \\ Email: asdarku [AT] gmail.com
}

\begin{abstract}
The purpose of this study was to create an e-flipped classroom learning paradigm to help mathematics students enhance their higher order thinking skills. This study is a research development, often known as R\&D. In this study, the development model proceeded through the stages of conceptual model, theoretical model, hypothetical model, and final model. The learning devices created in the form of prototypes are restricted to eight disciplines as a consequence of the design of learning devices achieved. The method for building the e-flipped classroom model to increase higher order thinking abilities is separated into three stages: pre-development activities, development activities, and model implementation activities. Validation sheets, observation sheets, questionnaires, and assessment sheets were utilized as study instruments. Validity, practicability, and effectiveness data analysis approaches are employed. The study's findings show that: (1) the e-flipped classroom model was developed to improve the parts that have been obstacles to its use thus far; (2) the flipped classroom model is not only a combination of online and offline but also allows for full online conditions; (3) the model is designed to train students' high-level thinking skills through several supportive activities; and (4) the devices used. Thus, based on the study findings, the e-flipped classroom concept and its learning aids satisfy the requirements for being valid, practical, and successful.
\end{abstract}

Keywords--- Floating, E-Flipped Classroom, Higher Order Thinking Ability, Mathematics

\section{INTRODUCTION}

In the period of the Fourth Industrial Revolution, education is becoming increasingly crucial in ensuring that pupils have 21 st century knowledge abilities. Higher Order Thinking Skills, problem solving, metacognition, communication abilities, cooperation, creativity and invention, information literacy, and numerous other skills are required in responding to the problems of the industrial revolution period that must be enabled in learning activities (Alismail \& McGuire, 2015; Chai \& Kong, 2017).

Higher Order Thinking Skills (HOTS) is an educational reform idea that began in the twenty-first century with the goal of preparing everyone to meet the advances of the Industrial Revolution 4.0 era. The HOTS domain includes a variety of mental processes such as information acquisition, critical thinking, creativity, and problem solving. It is possible to create thoughts on numerous solutions in everyday life by engaging in mental activities that are common to all human resources, such as those who are fast to make judgments based on reasonable and sophisticated thinking. However, pupils in Indonesia still have poor levels of higher order thinking skills.

According to statistics from The Trends International Mathematical and Science Study (TIMSS) 2015, Indonesia is remains behind the international average score for mathematics achievement, with a score of 397 (Grønmo et al., 2015). Furthermore, according to the 2018 Program for International Student Assessment (PISA) statistics, Indonesia is ranked in the bottom ten. With a score of 489, mathematical literacy skill is similarly below the worldwide average (OECD, 2019). Based on this statistics, it is known that Indonesian students' capacity to solve high-order thinking problems is still relatively 
poor, because TIMSS and PISA questions are classed as HOTS questions, such as creative thinking abilities.

Brookhrat divides HOTS into three areas in (Mahanal, 2019): (1) information and knowledge transmission, (2) critical thinking, and (3) problem resolution. Aside from that, students in the Mathematics Education Department are required to be critical thinkers as future mathematics instructors. This is reinforced by (Pratiwi, 2016) argument that if instructors (and potential teachers) are acclimated to critical thinking, they would urge their pupils to do the same. Meanwhile, (Pamungkas et al., 2019) assert that critical thinking abilities are crucial to student comprehension success. Thus, the combination of Islamic teaching ideals with science, particularly mathematics, is intended to increase students' critical thinking skills.

The capacity to think critically is a crucial skill to have while acquiring knowledge. According to Minister of National Education Regulation No.23 of 2006, about Graduate Competency Standards at the basic education level of competencies linked to studying mathematics.

At all stages of schooling, a person's critical thinking skills must be continually polished and strengthened. Because someone who is capable of critical thinking will be able to address difficulties successfully (Arifani et al., 2017; Dept of Educational Foundations, University of Lagos,- Lagos State, Nigeria \& Chukwuyenum, 2013; Peter, 2012). A person with strong critical thinking abilities will have a positive impact on his or her everyday life, as they will always make the proper and good judgments. This is reinforced by Ennis's remark in (As'ari \& Irawan, 2016) that critical thinking is rational and reflective thinking that focuses on making judgments about what to believe and what to do.

Based on observations during lectures, students of the Mathematics Education Department of UIN Alauddin Makassar in the first year of lectures are unable to answer issues linked to features of analysis, evaluation, and even invention in the introductory linear algebra course. One explanation is that kids are not accustomed to tackling issues involving the three cognitive elements and can only solve problems in the low cognitive domain. This will undoubtedly affect pupils' capacity to tackle related issues requiring higher-order thinking skills.

To solve these issues, it is important to enhance students' capacity in terms of high-level thinking, which is still poor, so that it does not occur continually. As a result, lecturers must foster higher-order thinking by selecting techniques or learning models that engage students in the learning process and accommodate thinking abilities so that students may experience their learning experiences.

The flipped classroom approach is one alternate strategy for improving higher-order thinking abilities, one component of which is the capacity to think critically. This strategy prepares students to be independent learners since they may access learning resources at any time and from any location by leveraging technology to assist learning materials. The flipped classroom approach is one component of the blended learning paradigm, which is an industrial revolution-era learning solution. 4.0. This model addresses the shortcomings of previous learning models that can develop higher-order thinking skills, such as the problem-based learning (PBL) model (Noma et al., 2016; Wiwin et al., 2017), Treffinger model (Sari \& Putra, 2015), and project-based learning model (Fitri et al., 2018; Niswara et al., 2019), which generally has a weakness in terms of time. To address the shortcomings of previous learning models in terms of time, the flipped classroom model is the best option because learning materials are studied by students outside of the classroom via online while in class it focuses on how to evaluate learning or how to train students' higher-order thinking skills.

The flipped classroom model design has three components: the transition to the flipped classroom, the design of learning outside the classroom, and the design of learning in the classroom. According to the researcher, the part of learning outside the classroom that requires a more specific design is the design of learning outside the classroom, because this feature causes the appearance of some of the previously identified shortcomings. In the flipped classroom approach, this is a component of e-learning.

The researcher is interested in creating the e-Flipped Classroom Learning Model to Improve Higher Order Thinking Skills for Mathematics Students based on the problem's background.

\section{RESEARCH METHOD}

This sort of study is referred to the development model proceeded through the stages of conceptual model, theoretical model, hypothetical model, and final model. The (Plomp \& Nieveen, 2010) model was utilized in this study, and it comprises of many phases, including: (1) preliminary inquiry, (2) design phase, (3) realization/construction phase, (4) phase of performing tests, evaluations, and revisions, and (5) implementation phase.

The method for building the e-flipped classroom model to increase higher order thinking abilities is separated into three sets of activities: pre-development, development, and model application. In this study, the following tools were used: validation sheets, observation sheets, questionnaires, and assessment sheets. An instrument validation sheet, a learning device validation sheet, and a model validation sheet comprise the validation sheet. The observation sheet is divided into three sections: one for the application of the learning model, one for lecturers' capacity to supervise learning, and one for student activities. 


\section{RESULT AND DISCUSSION}

\subsection{Preliminary Investigation}

According to the findings of the preliminary research, the Elementary Linear Algebra lecture process has been employing the lecture technique and a single textbook. Lectures are only delivered in one direction. Theoretical textbooks are difficult for pupils to grasp, making them less inclined to study independently. Students frequently wait for the professor to explain anything. Students are only taught to work on mathematical problems that the teacher assigns to them. As a result, pupils will face a variety of challenges when confronted with or addressing mathematical issues that are not or have not been instructed by the teacher.

As a result, children require extra assistance in overcoming learning difficulties. It is expected that lecturers would use learning models that can and their thinking abilities in learning activities. The flipped classroom model is one of the learning approaches that can assist students in improving their thinking abilities. The flipped classroom concept encourages students to study autonomously rather than expecting the lecturer to convey all of the content.

\subsection{Design Phase}

This design step entails creating an e-flipped classroom model book, learning tools, and research instruments. The design of the e-flipped classroom model book culminates in determining the structure of the e-flipped classroom model book, which comprises (1) rationality, (2) supporting theory, (3) components, and (4) implementation directions.

The justification for establishing the e-flipped classroom model comprises issues that are the primary concerns or the foundation for the necessity of developing the e-flipped classroom model book. Furthermore, this part summarizes the findings of important research that supports the construction of the e-flipped classroom model book. The components of the e-flipped classroom model, as well as the topics covered by each of these components, are explained in the model component section. The components of the e-flipped classroom model correspond to the model components described by (Joyce et al., 2011), which include the following elements: (1) syntax, (2) social system, (3) response principle, (4) support system, and (5) educational impact and accompaniment. The section on implementation instructions explains the e-flipped classroom model's implementation guidelines. The directions for implementing the e-flipped classroom model are as follows: (1) planning tasks, (2) instructions for executing the e-flipped classroom model, and (3) evaluation. The items that need to be prepared so that learning using the e-flipped classroom model may take place practically and successfully are discussed in the section on preparation assignments. These comprise the development of objectives, the selection of lecture materials, and the analysis of assignments as stated in the form; (1) semester program plans, (2) lecture program units, (3) e-modules, (4) student worksheets (LKM), and (5) assessment tools.

The learning devices designed in the form of prototypes are limited to eight subjects, namely systems of linear and matrix equations, determinants, vectors in 2-dimensional and 3-dimensional space, Euclidean vector space, and general vector space, product space. inside, eigenvalues and eigenvectors, and linear transformations.

The semester program plan (RPS) that was successfully designed was based on the syntax of the e-flipped classroom model, which consisted of pre-class activities and in-class activities, as well as taking into account its relationship with other components in the e-flipped classroom model, namely the social system, reaction principle, support system, and instructional impact and accompaniment. The semester program design (RPS) consists of the following components: (1) course achievement (CPMK), (2) indicators, (3) learning techniques, (4) learning materials, (5) learning resources, (6) learning media, (7) learning stages, and (8) assessment weight.

The lecture program unit (SAP) is based on the semester program plan (RPS) that was previously created utilizing the e-flipped classroom paradigm. The SAP design includes the following elements: (1) courses, (2) credit weights, (3) time allocation, (4) lecture materials, (5) learning outcomes, (6) planned final abilities, (7) indicators, (8) learning materials, (9) learning methods, (10) media, tools, and learning resources, (11) learning activities, and assessment of learning outcomes.

At this point, the student worksheets that were effectively prepared were 12 LKMs based on the amount of SAPs. Student worksheets are developed in the form of exercises that may be completed independently or in groups, together with training in higher-order thinking abilities and Islamic principles. Students are supposed to be able to think at a high level and comprehend Islamic principles via the application of this LKM in order to solve simple linear algebra difficulties and other challenges.

Learning outcomes assessments, higher order thinking skill tests, and assignments are examples of effective evaluation methods. The learning outcomes test is intended to assess pupils' cognitive abilities. This test not only assesses students' thinking skills based on their knowledge, comprehension, and application, but also on their levels of analysis, assessment, and creativity (higher order thinking skills). The lecturer must create a test based on the learning objectives to be attained in order to assess students' thinking skills in solving mathematical problems after engaging in learning activities. This exam is created with fundamental competencies and indications in mind, and it is then administered to pupils. Meanwhile, the 
activities are meant to assess students' cognitive capacity and are assigned to students during pre-class and in-class learning. These assignments are also intended to be used as an assessment tool in the e-flipped classroom paradigm of learning. The next evaluation tool is a higher order thinking skills exam, which explicitly attempts to measure higher order thinking abilities, particularly students' critical thinking skills in problem solving.

There are three types of instruments that have been designed: instruments of validity, instruments of practicality, and instruments of efficacy. The validity instruments developed during this design phase are as follows: (1) a validation sheet for observing the implementation of learning using the e-flipped classroom module, (2) a validation sheet for observing lecturers' ability to manage learning, (3) a validation sheet for observing student activities, and (4) a questionnaire validation sheet for lecturers' and students' responses to learning with the e-flipped classroom module. (5) validation sheet for e-flipped classroom model book, (6) validation sheet for RPS, (7) validation sheet for SAP, (8) validation sheet for emodule, (9) Validation sheet for MFI, (10) Validation sheet for assessment tool Learning outcomes assessments, higher order thinking skill exams, and activities are examples of evaluation tools. Meanwhile, the successful practical instruments designed in this phase were: (1) the observation sheet for the implementation of learning with the e-flipped classroom model, (2) the lecturer's ability sheet in managing learning, and (3) the lecturer's response questionnaire to learning with the e-flipped classroom model. While the effectiveness instruments developed during this phase include: (1) student activity observation sheets, (2) learning outcomes assessments, and (3) higher order thinking skills tests.

\subsection{Realization Phase}

The outcomes of the pre-development stage (initial inquiry and design) are reflected and re-examined before being directed to the realization in the form of a prototype: (a) e-flipped classroom model guidelines; (b) learning tools; and (c) instrumentation

In terms of learning tools, the e-flipped classroom model includes the following: (1) Semester Learning Plans (RPS), (2) Lecture Program Units (SAP), (3) Learning E-Modules, (4) Worksheets Student (LKM) consisting of LKM 1 and LKM 2 , and assessment tool 4 .

The semester learning plan is based on the grammar of the e-flipped classroom model, as well as its interaction with other components of the e-flipped classroom model, namely the response principle, social system, and instructional effect and accompaniment. The lecturer uses the semester learning plan as a guide in arranging students for the implementation of classroom learning and e-learning.

The Lecture Program Unit (SAP) is designed to explain the lesson plans or learning stages for each meeting in the form of a lecture program unit (SAP) consisting of six SAPs for six sessions. The researcher's SAP content design includes: 1) course information, 2) learning outcomes, intended final abilities, indicators, resources, models, and learning media, and 3) learning media, 3) The activity phases are split into two categories: pre-learning activities and post-learning activities. Classes and activities in the classroom are also classified as either online or offline, 4) Evaluation of learning outcomes

The E-Module that lecturers and students will use to study is intended to help students achieve learning skills and to pique students' interest in learning elementary linear algebra. The e-module compiled by researchers differs from other emodules in that it contains elementary linear algebra material based on a scientific approach and is equipped with learning videos, making learning feel more meaningful because students act as student centered learning through a scientific approach. In addition to having an appealing design and learning materials that are organized logically, the case examples in the e-module are contextually linked with Islamic principles. This is what distinguishes the e-module developed by academics from the elementary linear algebra textbooks formerly utilized by lecturers and students.

According to the number of SAPs for each LKM, student worksheets created by researchers are separated into two halves, LKM 1 and LKM 2. LKM that is created in the form of group work in pre-class activities utilizing LKM 1. This LKM is also intended to develop students' higher-order thinking abilities by using HOTS-based questions.

\subsection{Performing tests, evaluations, and revisions phase}

In the previous step, an e-flipped classroom Propotype-1 Model was created, which included: model books, learning tools, and instruments (validity, practicality, and effectiveness). At this point, these findings are being followed up on. Validation and testing operations are included in this level.

An expert performed the validation of the e-flipped classroom model prior to testing (validator). Validation activities are carried out by supplying validators with a script (e-flipped classroom model book) as well as the validation sheet. The validators offer evaluations and corrections on both the validation sheet and the validated text, and they declare that the eflipped classroom model can be utilized in the trial stage after being changed in line with the suggestions for improvement in the e-flipped classroom model book. 
The calculated average value for overall validity of the e-flipped classroom model is $\bar{x}=4.11$. The average value of the validity of the model of e-flipped classroom to support the theoretical elements of the model of e-flipped classroom is $\bar{x}=$ 4. The average value of the validity of the e-flipped classroom model to features of syntax $\bar{x}=4,17$. The average value of the validity of the e-flipped classroom model for the social system element is $\bar{x}=4.25$. The average value of the validity of the e-flipped classroom model for the response principal aspect is $\bar{x}=4$. The average value of the validity of the e-flipped classroom model for the support system component is $\bar{x}=4.25$. The average value of the e-flipped classroom model's validity for features of educational effect and accompaniment is $\bar{x}=4.1$. The average value of the e-flipped classroom model's validity for the instructional implementation element is $\bar{x}=4.3$. The average value of the e-flipped classroom model's validity for the language aspect is $\bar{x}=4.5$.

Furthermore, the validation findings for the e-flipped classroom model learning tools, acquired SAP, and assessment tools all fall into the "Very Valid" category, with intervals of 4.3. Meanwhile, RPS, learning e-modules, LKM, and attitude assessment test evaluation tools fulfill "Valid" requirements, namely at 3.5 intervals. However, some features of these tools, according to the expert team (validators), still need to be enhanced or added before the learning tools can be certified acceptable for usage.

The e-flipped classroom model was tested twice until a model that satisfied the practical and effective requirements was found. For the 2020/2021 academic year, the experiment was conducted in classes A and B. Trial 1 had 35 pupils from class A, whereas Trial II included 33 students from class B. The two courses were chosen at random with the premise that all classes are homogenous since students are placed in these classes at random (not based on ranking).

\subsection{Trial I}

The findings of monitoring the execution of the e-flipped classroom model in the first trial demonstrate that virtually all features of the e-flipped classroom model can be fully implemented. However, it must be continued in Trial II due to the fact that implementation restrictions are still there, owing to the fact that students and lecturers are not acclimated to utilizing the e-flipped classroom model. As a result, the changes focused on the application of learning approaches rather than models and learning tools.

Based on the study of the lecturer's response to the learning process, it is clear that the lecturer has a very positive attitude toward learning using the e-flipped classroom model. The lecturer believes that the learning technique employed is highly relevant in today's digital era. However, it is still necessary to revise the part that is still considered lacking by the lecturer or the response of the lecturer who has not been positive, namely the language aspect of the LKM that needs to be clarified, particularly the narration of sometimes ambiguous questions and aspects of model guidelines that need to be clarified in the model implementation technique.

Furthermore, the average score of lecturers' skills was good from the ideal score of 5 based on the findings of data analysis on the capacity of lecturers to manage learning with the e-flipped classroom model in Trial I (in good category). As a result, the lecturer's ability to handle the e-flipped classroom approach is commendable. Although lecturers' ability to manage learning using the e-flipped classroom model is generally strong, one of the stages in the syntax that needs to be addressed by the lecturers in Trial II is the activity phase in the classroom (phase 3 and phase 6).

According to the data analysis of student learning outcomes in the first experiment, only 71.4 percent of students, or 25 of 35 students, scored 65 or above in terms of completeness. This indicates that the student learning results did not meet the criteria for completion. Furthermore, the examination of higher order thinking skills in the first attempt revealed that students with higher order thinking abilities above 78 accounted for 77.1 percent of the students, or as many as 27 of 35 . This demonstrates that it does not satisfy the requirements.

The study of student responses shows that, in general, students are satisfied with learning using the e-flipped classroom model, the learning environment that includes both face-to-face and e-learning, and the manner the lecturer teaches. The majority of students stated that learning activities employing the e-flipped classroom paradigm were novel to them. Students have expressed a strong desire to participate in learning activities using the e-flipped classroom approach, as evidenced by their replies. Students fully grasp the criteria for the e-flipped classroom model, the examinations provided, and the lecturers' teaching methods. Furthermore, students are excited by the emergence of the e-flipped classroom model of learning tools. Students' opinions on learning differ, but in general, they give positive feedback on how learning is implemented.

According to the findings of the first trial's study of student activity data, there were only three categories of 12 types of activities, which were separated between activities outside the classroom (online) and activities in the classroom (offline). However, three essential activities, namely activities outside the classroom and activities inside the school, have yet to be completed. As a result, student actions in the first experiment did not fulfill the criterion. 


\subsection{Trial II}

In terms of model implementation, where the observation sheet on the implementation of the e-flipped classroom model used in the second trial is empirically reliable based on the results of the first trial's analysis, the data obtained in the second trial is appropriate to be used to assess the model's practicability. Then, based on the study of the lecturer's reaction, it can be observed that the lecturer responded very positively to learning utilizing the e-flipped classroom model, with an overall average of 100 percent.

Based on the findings of data analysis on lecturers' capacity to manage learning with the e-flipped classroom model in Trial II, the average score of lecturers' skills was 4.65 out of a possible five points (in the very good category). Thus, lecturers' ability to manage learning using the e-flipped classroom model is as predicted, indicating that lecturers' ability to manage learning using the e-flipped classroom model is generally good.

According to the data analysis of student learning outcomes in the second experiment, 85 percent of students, or 28 of 33 students, scored 65 or above in terms of completeness. This demonstrates that the student learning outcomes meet the requirements for completeness. Furthermore, the examination of higher order thinking skills in the second trial revealed that individuals with higher order thinking abilities above 78 accounted for 87.9 percent of the total, or 29 of the 33 students. This demonstrates that it satisfies the conditions.

The study of student answers revealed that, in general, students were pleased with the learning activities utilizing the e-flipped classroom model, the devices utilized, the learning atmosphere both face-to-face and e-learning, and the lecturer's teaching style. The majority of students answered that learning activities based on the e-flipped classroom paradigm are novel. Students have expressed a strong desire to participate in learning activities using the e-flipped classroom approach, as evidenced by their replies. Students easily grasp the e-flipped classroom model's principles, tools, competence assessments for learning outcomes, and how lecturers educate. Furthermore, students are intrigued by the introduction of the e-flipped classroom model of learning tools, particularly case studies with contextual and Islamic aspects.

The findings of the first trial's analysis of student activity data from 12 categories of activities separated into activities outside the classroom (online) and activities in the classroom (offline) fulfilled the requirements extremely well. As a result, the student actions in the second experiment satisfied the stated requirements.

\subsection{Final Product Specification}

The e-flipped classroom approach was created to address the shortcomings that have hampered its adoption in the past. The following are some of the qualities or specs of the items developed:

\section{Characteristics 1}

Documentation of assignments delivered outside the classroom (online) in the form of an e-portfolio is one of the additional tasks in the evaluation section. This task is designed to determine if students actively participate in learning outside of the classroom (online learning).

\section{Characteristics 2}

The current state of complete online learning prevents the flipped classroom model from functioning correctly, particularly activities in the classroom via face-to-face meetings. This sparked the notion to create a flipped classroom paradigm that is not only a hybrid of online and offline, but also allows for full online conditions. As a result, there are two options for activities in the classroom: offline or online via synchronous communication.

Characteristic 3

According to (Protheroe, 2007), there are six things that must be done in mathematics class to utilize students' higher order thinking skills, including: (1) actively engage in doing mathematics; (2) solve challenging problems; (3) make interdisciplinary connections; and (4) share mathematical knowledge.

According to (Protheroe, 2007), five of the six tasks that can use higher order thinking abilities are included in the created e-flipped classroom model, namely: (1) Student activity in performing arithmetic exercises, (2) Solve difficult math problems, (3) Connecting with people from diverse fields, (4) Discuss mathematical concepts, (5) Using a variety of methods to express mathematical ideas.

\section{Characteristics 4}

One of the numerous teaching design concepts is the principle of teaching as interaction. This idea recognizes that education is a complicated process involving several learning actors. These learning actors rely on one another. Furthermore, this concept can offer an overview of the interactions that occur between learning actors in remote learning (online). Finally, this concept opens the door to current learning techniques that involve student engagement in an online 
learning environment, such as computer-assisted collaborative learning.

\subsection{Final Product Review}

The model of e-flipped classroom that was developed is based on the logic to believe that by learning to use the model of e-flipped classroom, students can develop the capacity to think through problem-solving skills through a variety of learning resources that vary both through traditional learning and online learning (e-learning).

The e-flipped classroom approach is based on the core assumption that everyone will create new forms of knowledge by integrating information that comes in, then with what has been stored in memory, the outcomes of past learning. This is consistent with (Burns et al., 1996) constructivism learning theory, which argues that much of what people learn and comprehend is formed or built by them. According to constructivism, the e-flipped classroom approach allows students to construct their own knowledge through classroom instruction or independent study via e-learning.

In fact, achieving competency necessitates a range of techniques that allow students to get direct experience and feedback through traditional learning. Whereas the e-flipped classroom model allows traditional learners to access learning resources via e-learning, it also provides for face-to-face learning via the big blue button facility, Google Meet, and numerous other apps. Overall, this study found evidence that the creation of the e-flipped classroom model in the Elementary Linear Algebra course may be used and improved to improve the quality of the teaching and learning process in higher education. As a result, a learning process equipped with learning tools (RPS, SAP, e-Module, LKM) for both lecturers and students might synergize with the e-flipped classroom model, particularly for the goal of improving the learning process.

\section{CONCLUSION}

The e-flipped classroom model has several features, including (1) the e-flipped classroom model was created to enhance the aspects that had previously been barriers to its usage. The improved part is how to design learning outside the classroom (online learning) to ensure active students, namely by including activities in the evaluation section in the form of documentation of assignments given outside the classroom (online) in the form of an e-portfolio, (2) a flipped classroom model that allows for full online conditions rather than just a combination of online and offline conditions. As a result, there are two options for activities in the classroom: offline or online via synchronous communication. (3) The approach is intended to develop students' higher-order thinking abilities through a variety of supportive activities; and (4) the technology utilized, particularly the e-module, is intended to be appealing and to be connected with Islamic principles.

The e-flipped classroom concept and its learning aids satisfy the requirements for being valid, practical, and successful. The assessment of experts and practitioners indicates the validity of criteria. The adoption of the e-flipped classroom model, lecturer reactions, and lecturers' abilities to control learning are all practical factors. Student actions in learning, student responses to learning, attainment of student learning goals competency, and high-level thinking skills of students are effective criteria.

\section{REFERENCES}

[1] Alismail, H. A., \& McGuire, D. P. (2015). 21st Century Standards and Curriculum: Current Research and Practice. Journal of Education and Practice, 6(6), 6.

[2] Arifani, N. H., As'ari, A. R., \& Abadyo, A. (2017). PROSES BERPIKIR SISWA KELAS VIII DALAM MENYELESAIKAN SOAL MATEMATIKA TIMSS MATERI BESAR SUDUT DALAM BENTUK GEOMETRIS. Jurnal Pendidikan: Teori, Penelitian, dan Pengembangan, 2(7), 946-954. https://doi.org/10.17977/jptpp.v2i7.9677

[3] As'ari, A. R., \& Irawan, E. B. (2016). Variasi Konstruk Dalam Pembelajaran Matematika. Bintang Sejahtera.

[4] Burns, P. C., Roe, B. D., \& Ross, E. P. (1996). Teaching Reading In today's Elementary School. Houghton Mifflin.

[5] Chai, C. S., \& Kong, S.-C. (2017). Professional learning for 21 st century education. Journal of Computers in Education, 4(1), 1-4. https://doi.org/10.1007/s40692-016-0069-y

[6] Dept of Educational Foundations, University of Lagos,- Lagos State, Nigeria, \& Chukwuyenum, A. N. (2013). Impact of Critical thinking on Performance in Mathematics among Senior Secondary School Students in Lagos State. IOSR Journal of Research \& Method in Education (IOSRJRME), 3(5), 18-25. https://doi.org/10.9790/7388-0351825

[7] Fitri, H., Dasna, I. W., \& Suharjo, S. (2018). Pengaruh Model Project Based Learning (PjBL) Terhadap Kemampuan Berpikir Tingkat Tinggi Ditinjau dari Motivasi Berprestasi Siswa Kelas IV Sekolah Dasar. Briliant: Jurnal Riset Dan Konseptual, 3(2), 201-212. https://doi.org/10.28926/briliant.v3i2.187

[8] Grønmo, L. S., Lindquist, M., Arora, A., \& Mullis, I. V. S. (2015). T15 Frameworks Full Book. Timss \& Pirls. https://timssandpirls.bc.edu/timss2015/downloads/T15_Frameworks_Full_Book.pdf

[9] Joyce, B., Weil, M., \& Calhoun, E. (2011). Models of Teaching: Model-Model Pengajaran (8th Ed). Pustaka Pelajar. 
[10] Mahanal, S. (2019). View of Asesmen Keterampilan Berpikir Tingkat Tinggi. Jurnal Penelitian Dan Pengkajian Ilmu Pendidikan: E-Saintika, 3(2), 1-23.

[11] Niswara, R., Muhajir, M., \& Untari, M. F. A. (2019). Pengaruh Model Project Based Learning Terhadap High Order Thinking Skill. MIMBAR PGSD Undiksha, 7(2), Article 2. https://doi.org/10.23887/jjpgsd.v7i2.17493

[12] Noma, L. D., Prayitno, B. A., \& Suwarno, S. (2016). Problem Based Learning to Improve HOTS of High School Students. Bioedukasi: Jurnal Pendidikan Biologi, 9(2), 62-66. https://doi.org/10.20961/bioedukasi-uns.v9i2.4222

[13] OECD. (2019). PISA 2018 Results: COMBINED EXECUTIVE SUMMARIES VOLUME I, II \& III.

[14] Pamungkas, D., Mawardi, M., \& Astuti, S. (2019). Peningkatan Keterampilan Berpikir Kritis dan Hasil Belajar Matematika Pada Siswa Kelas 4 Melalui Penerapan Model Problem Based Learning. Jurnal Ilmiah Sekolah Dasar, 3(2), 212-219. https://doi.org/10.23887/jisd.v3i2.17774

[15] Peter, E. (2012). Critical thinking: Essence for teaching mathematics and mathematics problem solving skills. African Journal of Mathematics and Computer Science Research, 5(3), 39-43. https://doi.org/10.5897/AJMCSR11.161

[16] Plomp, T., \& Nieveen, N. M. (2010). An introduction to educational design research: Proceedings of the seminar conducted at the East China Normal University, Shanghai (PR China), November 23-26, 2007 (SLO, Enschede). SLO. file://C:/Users/lenovo/AppData/Local/Temp/educational-design-research-part-a.pdf

[17] Pratiwi, D. (2016). ANALISIS KETERAMPILAN BERPIKIR KRITIS MAHASISWA CALON GURU BIOLOGI MELALUI PEMBELAJARAN KOOPERATIF PADA MATA KULIAH DESAIN PEMBELAJARAN 2014/2015. Jurnal Pendidikan Matematika Dan IPA, 6(2), 13-25. https://doi.org/10.26418/jpmipa.v6i2.17336

[18] Protheroe, N. (2007). What Does Good Math Instruction Look Like? Principal, 5.

[19] Sari, Y. I., \& Putra, D. F. (2015). Pengaruh Model Pembelajaran Treffinger terhadap Kemampuan Berpikir Kritis dan Kreatif Mahasiswa Universitas Kanjuruhan Malang. Jurnal Pendidikan Geografi: Kajian, Teori, dan Praktek dalam Bidang Pendidikan dan Ilmu Geografi, 20(2), 30-38. https://doi.org/10.17977/jpg.v20i2.290

[20] Wiwin, W., Sujana, A., \& Julia, J. (2017). PEMBELAJARAN BERBASIS MASALAH DALAM MENINGKATKAN KETERAMPILAN BERPIKIR KREATIF SISWA KELAS III SDN SUKARAJA II PADA MATERI PELESTARIAN LINGKUNGAN. Jurnal Pena Ilmiah, 2(1), 341-350. https://doi.org/10.17509/jpi.v2i1.10669 